\title{
Ethiopia, 2019
}

\author{
Anbessaw Wolde' \\ Dereje Haile ${ }^{2}$ \\ Ufaysa Anjulo' \\ Jegnaw Wolde'
}

'Wolaita Zone Health Department, Sodo, Southern Ethiopia, Ethiopia; ${ }^{2}$ Departments of Reproductive Health and Nutrition, School of Public Health, College of Medicine and Health Science, Wolaita Sodo University, Sodo, Southern Ethiopia, Ethiopia
Correspondence: Dereje Haile Email derehaile20I0@gmail.com
This article was published in the following Dove Press journal: Open Access Journal of Contraception

Background: The ability of individuals and couples to anticipate and achieve their desired number of children as well as the spacing and timing of their birth is family planning. Access to family planning and ensuring that needs are met is based on human rights. Nonetheless, for most women, this need has not been met. In addition, in this study field, there was minimal evidence regarding this. Thus, the aim of this study was to assess the prevalence and associated factors of unmet need of modern contraceptive methods among currently married women in Damot Woyde district, southern Ethiopia.

Methods: This community based cross-sectional study was conducted from February 20 to 28, 2019. A multi-stage sampling procedure was employed to select 658 currently married women of child-bearing age in the study areas. A pretested interviewer administered questionnaire was used for data collection. Bivariate and multivariate logistic regression analyses were used to identify the predictors of dependent variables and the adjusted odds ratios with its $95 \%$ confidence interval was used to report the level of association. Variables with a $P$-value $<0.05$ were considered as statistically significant.

Results: The total unmet need for modern contraceptive methods was $169(26.3 \%$; $95 \% \mathrm{CI}=$ 22.9-29.7\%) among currently married women for the study participants. In multiple logistic regression analysis, educational status $(\mathrm{AOR}=4.3 ; 95 \% \mathrm{CI}=1.1-14.7)$, women with five or more, and three-to-four children(AOR $=4.3 ; 95 \% \mathrm{CI}=1.4-13.1$ and $\mathrm{AOR}=2.8 ; 95 \% \mathrm{CI}=1.1-7.8$, respectively), little perceived risk of pregnancy due to infrequent sexual intercourse (AOR $=2.2 ; 95 \%$ $\mathrm{CI}=1.3-3.8$ ), and little perceived risk of pregnancy due to breast feeding ( $\mathrm{AOR}=2.3 ; 95 \%$ $\mathrm{CI}=1.3-4.10)$ were factors associated with the unmet need of modern contraceptive methods.

Conclusion and Recommendation: This study revealed that unmet need for modern contraceptive methods was found to be high compared to the national and regional figures. Therefore, community health workers and health professionals should be strengthening communication and discussion at grass root level in order to promote the right time for using family planning. District health office and other concerned bodies should collaborate with the education office to expand formal and non-formal education for women in order to decrease the unmet need for modern contraceptive methods.

Keywords: unmet need, contraceptive, Ethiopia

\section{Plain Language Summary}

Family planning (FP) is the ability of individuals and couples to anticipate and attain their desired number of children and the spacing and timing of their birth. The right to family 
planning and reproductive health services has been enshrined in a number of international agreements and strategies; therefore, governments are obligated to ensure these aims are met. Moreover, under Sustainable Development Goals 3 (SDGs), universal access to sexual and reproductive healthcare services, including family planning, were established. In addition, a variety of NGO services have been given in this study area to improve the uptake of family planning. Nevertheless, there has been little evidence of the extent of unmet need for modern contraception. The goal of this study was, therefore, to determine the level of unmet need and its associated factors among married women in the district of Damot Woyde, southern Ethiopia, in 2019.

A systematic random sampling method was conducted to recruit 658 individuals in this study. The association between the dependent and explanatory variable was assessed by using the binary logistic regression model. Accordingly, educational status, total number of living children, little perceived risk of pregnancy due to infrequent sexual intercourse, and little perceived risk of pregnancy due to breast feeding were factors associated with the unmet need of modern contraceptive methods. Therefore, community health workers and health professionals should be strengthening communication and discussion at grass root level in order to promote the right time for using family planning.

\section{Background}

Modern contraceptive methods are products or medical procedures that interfere with reproduction through acts of sexual intercourse. Sterilization (male and female), intrauterine devices and systems, subdermal implants, oral contraceptives, condoms (male and female), injectables, tablets for emergency contraception, patches, diaphragms and cervical caps, spermicidal agents (gels, foams, creams, suppositories, etc.), vaginal rings, and sponges are all forms of modern contraceptives. ${ }^{1}$

Family planning (FP) is the ability of individuals and couples to anticipate and attain their desired number of children and the spacing and timing of their birth. ${ }^{2}$ Currently, provision of contraceptives through outreach, which is driven by non-governmental organizations and government as a backup, methods is used as a strategy to improve the sexual and reproductive health of women. ${ }^{2}$

According to ICPD 1994, accessing of family planning is considered as a human right, and governments are obligated to ensure it. ${ }^{3}$ Moreover, ensuring universal access of family planning was one of the targets of Sustainable Development Goal 3 (SDGs) to end preventable maternal deaths through the integration of reproductive health into national strategies and programs. ${ }^{4}$
The government of Ethiopia committed and launched reproductive health strategies to ensure the utilization of quality family planning (FP) services through reducing the unmet need for contraception from 25 to 10 , and increasing contraceptive prevalence to $55 \%$ among married women. ${ }^{5}$

Despite it's insight by government, and its embedment and recognition as a human right, globally in $2017,12 \%$ of married or in-union women are estimated to have an unmet need for family planning. Moreover, there were great WHO regional variations in level of unmet need for modern contraceptive methods. The level was higher in Africa (22\%) and Oceania (15\%) compared to other regions, where the unmet need for family planning is estimated to be at or below $10 \%$ for married or in-union women. ${ }^{6}$ Similarly, over the last 25 years, in Ethiopia, there was an around 6-fold increase in coverage of demand satisfied for modern contraceptive use (14\% in 2000 to $61 \%$ in 2016). Despite that, the 2016 EDHS report revealed a high prevalence of unmet need for family planning even if it declined from $37 \%$ in 2000 to $22 \%$ in 2016). ${ }^{7}$

Moreover, the min-EDHS (2019) reported that, overall, $41 \%$ of currently married women are using modern methods of family planning. By region, the CPR ranges from $3 \%$ in Somali up to $50 \%$ in both the Amhara Region and Addis Ababa. ${ }^{8}$ This report indicates a big discrepancy of achieving targets of CPR of $55 \%$ by $2020 .^{5}$

However, even if there were a number of supports from non-governmental organizations to increase the uptake of family planning in this study area, and there is a lot of current information on the magnitude of unmet need for modern family planning and factors associated with it in our study area. Therefore, this study was aimed to assess the prevalence and associated factors for unmet need of modern family planning methods among currently married reproductive women.

\section{Methods}

\section{Study Area and Design}

Damot Woyde district is one of the 12 rural districts and three city administrations in the Wolaita Zone. It is located in the east part of Wolaita Zone and is $400 \mathrm{~km}$ from Addis Ababa, $171 \mathrm{~km}$ from the SNNP regional city of Hawassa, and $27 \mathrm{~km}$ from the Soddo (the zonal capital). There are 23 rural and two urban kebeles and it has an estimated population of 113,823 based on estimated projected figures from the Central Statistical Agency of Ethiopia (CSA, 2007). In total, there are four health centers and 27 health posts that provide family 
planning in the district. The physical health services coverage of the district was $88 \%$ in 2019. A community-based crosssectional study was done from February 20-28, 2019.

\section{Definition of Outcome Variables}

\section{Unmet Need of Modern Contraceptive Methods with Currently Married Women}

This variable measurement is complex. There were three criteria used to categorize women under unmet need for family planning. If a woman fulfilled one of the criteria for unmet need for family planning mentioned below, she was categorized under unmet need for family planning.

(i) Those women who are neither pregnant nor amenorrheic, but fecund women, and those who want to space or limit their fertility, but are not using modern contraceptive methods.

(ii) Those pregnant women whose pregnancy was mistimed or unwanted at the time when they became pregnant.

(iii) Postpartum amenorrheic women whose last birth was mistimed or unwanted and period not returned since last birth within last 2 years. ${ }^{9}$

\section{Unmet Need for Spacing}

The percentages of not pregnant women who want another child after 2 years and who are pregnant as a result of a mistimed pregnancy but not using any modern contraceptive methods.

\section{Unmet Need for Limiting}

The percentages of not pregnant women who do not want another child at all and who were pregnant as a result of unwanted pregnancy but not using any modern contraceptive methods.

\section{Measurements of Predictors Knowledge of Modern Contraception Methods}

This was measured by using six Yes or No questions related to contraception. A woman was knowledgeable if she scored a mean score or above mean, otherwise she was considered as non-knowledgeable. ${ }^{10}$

\section{Attitude Towards Modern Contraceptive Methods}

This was measured by using five Likert scale questions (strongly disagree to strongly agree). A woman was considered to have a positive attitude if she scored at mean or above the mean value, but if she scored below the mean she was categorized to have a negative attitude.

\section{Defaulter}

A woman was categorized under defaulter for family planning if she ever used family planning, but discontinued it during the survey period.

\section{Population}

All selected currently married women of childbearing age (15-49 years old) resided in Damot Woyde district formed the studied population. Those women who were of childbearing age (15-49 years old) that resided permanently for at least 6 months in the study area were included in this study and those women who were critically ill or cannot communicate were excluded from the study.

\section{Sample Size Determination}

The single population proportion formula was used to estimate the sample size of the study. The estimated prevalence of unmet need for modern contraception was obtained from studies done in Misha district, southern Ethiopia, at $26.5 \%,{ }^{11}$ and by assuming a confidence level of $95 \%$ and the desired margin of error of $5 \%$, this gave a total of 299 . So, by considering a $10 \%$ non-response rate and a design effect of 2, the total sample required was 658 .

\section{Sampling Procedure}

A multistage sampling technique was used to select the study subjects. By using simple random sampling methods, one urban and seven rural kebeles were selected. The required sample size was proportionally allocated to each kebele based on the number of households. Finally, a systematic random sampling method with 10th $\mathrm{k}$ interval was applied to select the households with women in the reproductive age group.

\section{Data Collection Methods and Procedures}

Data collectors were recruited from other nearby health institutions. Six diploma graduate midwifery nurses as data collectors, and one BSc midwifery and one public health officer who speak Amharic and Wolaitegna very well were recruited for supervision. Data in the form of survey were collected from women by using semistructured interview administered questionnaires. A pretested, structured, interviewer administered questionnaire was used. The questionnaire was adapted from EDHS and other published literatures. ${ }^{10,11}$ 


\section{Data Quality Management}

One day in-depth training was given to data collectors. Data collection was supervised by supervisors and the principal investigator. A pretest was conducted on $5 \%$ of the sample size from out of the study area to take every possible correction. Data were cleaned and checked for completeness on a daily basis.

\section{Data Analysis}

Data were edited, coded, and entered into Epidata version 3.1 and exported to SPSS 23 statistical software for analysis. After cleaning data for inconsistencies and missing value in SPSS, descriptive statistics were done. Bivariate analysis was done to determine the association between each independent variable and outcome variable. All predictor variables with a $P$-value less than 0.25 during the bivariate analysis were entered into the multivariable logistic regression model. Then multivariable logistic regression model using the backward stepwise selection method at a $P$-value $<0.05$ and AOR with $95 \%$ CI was used to measure the degree of association between independent variables and a dependent variable. During data analysis, no adjusting for sample design or cluster was conducted.

\section{Ethical Approval and Consent to Participate}

Ethical clearance was secured from the ethical clearance committee of the Wolaita Sodo University, College of Health Science and Medicine. The purpose, objectives, and importance of the study were explained and verbal informed consent was secured from each participant and approved by the Ethical board of Wolaita sodo university. They were told that documents will be kept confidential and have the right to refuse participation totally at any time if they were not comfortable. We confirmed that the study was conducted in accordance with the Declaration of Helsinki. Moreover, verbal informed consent was approved by the Ethical Clearance Committee of the Wolaita Sodo University, and that participants under the age of 18 years are legally able to provide such consent due to their marital status.

\section{Result}

Of 658 sampled study subjects, 643 were participated in this study given the response rate of $97.7 \%$.

\section{The Socio-Demographic Characteristics}

The mean age of the study participants was 23.8 ( $\mathrm{SD}=$ $\pm 4.6)$. The study participants were found to be followers of protestant religion $(482 ; 75 \%)$, housewifes $(449 ; 69.8 \%)$, unable to read and write $(213 ; 33.1 \%)$, and Wolaita ethnic (637; 99.1\%). The majority of the study participants had an income of $<400 \mathrm{ETB}$, and did not own a radio and TV (350; 54.4\%) (Table 1).

\section{Reproductive Characteristics}

One third (33.6\%) of the respondents were in the age range of below 18 years when they got married the first time. Among the study participants, 83 (12.9\%) were pregnant at the time of interview. Moreover, from the pregnant mothers, 11 (13.3) wanted a later pregnancy, and seven (8.4) did not want to be pregnant at all (Table 2).

\section{Knowledge and Attitude Towards Modern Contraceptives}

The overall level of good knowledge regarding contraception was $489(76 \%)$. Near to all the study respondents $(636 ; 98.9 \%)$ mentioned at least one modern family planning method. Regarding the source of information for contraception, more than two thirds $(439 ; 68.3 \%)$ was from health extension workers. The majority of the women knew about injectables $(621 ; 96.6 \%)$, while only 115 (17.9\%) knew about vasectomy. Regarding the attitude towards contraceptive methods, positive attitudes outweighed negative ones (Table 3).

\section{Family Planning Utilization}

Regarding family planning utilization, 292 (45.4\%) met the need for family planning, 161 (25\%) were defaulters for modern contraceptives, and 190 (29.5\%) of the study participants were not using any of the modern contraceptive methods. Of the total current users, 165 $(56.5 \%)$ used injectable family planning methods. Out of the 351 non-family planning users, 131 (37.3\%) were not using modern contraceptive methods for fear of sideeffects, $119(33.9 \%)$ due to husband's opposition, 115 $(32.8 \%)$ because they had no or infrequent sex, and 98 $(28.0 \%)$ because they were breastfeeding (Table 4$)$.

\section{The Prevalence of Unmet Need}

The total unmet need for modern contraceptive methods was 169 (26.3\%; 95\% CI=22.9-29.7) among currently married 
Table I Socio-Demographic Characteristics of Currently Married Women, Damot Woyde District, SNNPR, Ethiopia, $2019(\mathrm{~N}=643)$

\begin{tabular}{|c|c|c|c|}
\hline \multicolumn{2}{|c|}{ Characteristics $(\mathrm{N}=643)$} & \multirow{3}{*}{$\begin{array}{l}\text { Number } \\
126 \\
135\end{array}$} & \multirow{4}{*}{$\begin{array}{l}\text { Percent } \\
4.0 \\
21.0 \\
31.3\end{array}$} \\
\hline Age of mother (in & $15-24$ & & \\
\hline years) & $25-34$ & & \\
\hline & $35-49$ & 201 & \\
\hline \multirow[t]{4}{*}{ Religion } & Protestant & 482 & 75.0 \\
\hline & Orthodox & 144 & 22.4 \\
\hline & Catholic & 16 & 2.5 \\
\hline & Muslim & 1 & 0.2 \\
\hline \multirow[t]{7}{*}{ Occupation of mothers } & Housewife & 449 & 69.8 \\
\hline & Farmer & 24 & 3.7 \\
\hline & Merchant & 124 & 19.3 \\
\hline & Student & 26 & 4.0 \\
\hline & Government & 19 & 3.0 \\
\hline & employee & & \\
\hline & Others* & I & 0.2 \\
\hline \multirow[t]{5}{*}{$\begin{array}{l}\text { Educational status of } \\
\text { mothers }\end{array}$} & $\begin{array}{l}\text { Unable to write } \\
\text { and read }\end{array}$ & 213 & 33.1 \\
\hline & $\begin{array}{l}\text { Able to read and } \\
\text { write }\end{array}$ & 41 & 6.4 \\
\hline & Primary & 244 & 37.9 \\
\hline & Secondary & 91 & 14.2 \\
\hline & $\begin{array}{l}\text { Certificate and } \\
\text { above }\end{array}$ & 54 & 8.4 \\
\hline \multirow[t]{2}{*}{ Ethnicity } & Wolaita & 637 & 99.1 \\
\hline & Others** & 6 & 0.9 \\
\hline \multirow[t]{4}{*}{ Income } & $<400$ & 261 & 40.6 \\
\hline & $401-745$ & 192 & 29.9 \\
\hline & $746-1,220$ & 98 & 15.2 \\
\hline & $>1,220$ & 92 & 14.3 \\
\hline \multirow{4}{*}{$\begin{array}{l}\text { Ownership of Radio or } \\
\text { Television }\end{array}$} & Only radio & 234 & 36.4 \\
\hline & Only TV & 16 & 2.5 \\
\hline & $\begin{array}{l}\text { Both radio and } \\
\text { TV }\end{array}$ & 11 & 1.7 \\
\hline & None & 350 & 54.4 \\
\hline
\end{tabular}

Notes: *Unemployed. **Gurage, Amhara, Sidama.

women for the study participants. The unmet need for spacing is $121(18.8 \%)$ and 48 (7.5\%) for limiting.

\section{Determinants of Unmet Need for Modern Contraceptive Method}

Possible explanatory variables were assessed in association with unmet need for modern contraceptives in the bivariate analysis in the study area. Among these factors, age, occupation and educational level, total number of living children, mother attitude and knowledge about one
Table 2 Reproductive Characteristics Among Currently Married Women, Damot Woyde District, SNNPR, Ethiopia, 2019 $(\mathrm{N}=643)$

\begin{tabular}{|c|c|c|c|}
\hline \multicolumn{2}{|l|}{ Characteristics } & Number & Percent \\
\hline Age at first marriage & $\begin{array}{l}\text { Below } 18 \\
18-24 \\
25-34\end{array}$ & $\begin{array}{l}216 \\
411 \\
16\end{array}$ & $\begin{array}{l}33.6 \\
63.9 \\
2.5\end{array}$ \\
\hline Total living children & $\begin{array}{l}\text { No children } \\
1-2 \\
3-4 \\
5 \text { and above }\end{array}$ & $\begin{array}{l}57 \\
195 \\
171 \\
220\end{array}$ & $\begin{array}{l}8.9 \\
30.3 \\
26.6 \\
34.2\end{array}$ \\
\hline Currently pregnant & $\begin{array}{l}\text { Yes } \\
\text { No } \\
\text { Unsure }\end{array}$ & $\begin{array}{l}83 \\
546 \\
14\end{array}$ & $\begin{array}{l}12.9 \\
84.9 \\
2.2\end{array}$ \\
\hline $\begin{array}{l}\text { Whether the current } \\
\text { pregnancy was wanted } \\
(n=83)\end{array}$ & $\begin{array}{l}\text { Wanted now } \\
\text { Wanted later } \\
\text { Not wanted at } \\
\text { all }\end{array}$ & $\begin{array}{l}65 \\
11 \\
7\end{array}$ & $\begin{array}{l}78.3 \\
13.3 \\
8.4\end{array}$ \\
\hline $\begin{array}{l}\text { Wanted last birth (for } \\
\text { postpartum amenorrheic } \\
\text { women) }(n=75)\end{array}$ & $\begin{array}{l}\text { Wanted } \\
\text { Wanted later } \\
\text { Not wanted at } \\
\text { all }\end{array}$ & $\begin{array}{l}38 \\
32 \\
5\end{array}$ & $\begin{array}{l}50.6 \\
42.7 \\
6.7\end{array}$ \\
\hline
\end{tabular}

FP, do not knew alternative choice of FP, visiting health facilities in the last 6 months, discussion with the partner, and little perceived risk of pregnancy due to infrequent sexual intercourse and little perceived risk of pregnancy due to breast feeding, and the outlook that FP improves mother and child health were identified as candidates for multivariable logistic analysis.

In multivariable logistic regression analysis, educational status, total number of living children, little perceived risk of pregnancy due to infrequent sexual intercourse and little perceived risk of pregnancy due to breast feeding were independently associated factors of unmet need for FP (Table 5).

The odds of unmet need for modern contraceptive was 4.7-times higher among women unable to read and write compared to those who were educated to the secondary and above level $(\mathrm{AOR}=4.3 ; 95 \% \mathrm{CI}=1.1-14.7)$. Women with five or more, and three-to-four children were associated with unmet need for modern contraceptive methods, compared to those with no children ( $\mathrm{AOR}=4.3 ; 95 \% \mathrm{CI}=1.4-13.1$; and $\mathrm{AOR}=2.8 ; 95 \% \mathrm{CI}=1.1-7.8$, respectively). Those study participants with little perceived risk of pregnancy due to infrequent sexual intercourse were 2.2-times more likely experienced unmet need for modern contraceptive methods 
Table 3 Knowledge and Attitude Towards Modern Contraceptive Methods Among Currently Married Women, Damot Woyde District, SNNPR, Ethiopia, 2019 ( $n=643)$

\begin{tabular}{|c|c|c|c|}
\hline \multicolumn{2}{|l|}{ Characteristics } & \multirow{2}{*}{$\begin{array}{l}\text { Number } \\
636 \\
7\end{array}$} & \multirow{2}{*}{$\begin{array}{l}\text { Percent } \\
98.9 \\
1.1\end{array}$} \\
\hline $\begin{array}{l}\text { Know about at least one } \\
\text { modern contraceptive }\end{array}$ & $\begin{array}{l}\text { Yes } \\
\text { No }\end{array}$ & & \\
\hline $\begin{array}{l}\text { Source of information for } \\
\text { contraceptive }\end{array}$ & $\begin{array}{l}\text { Health } \\
\text { extension } \\
\text { worker } \\
\text { Health } \\
\text { development } \\
\text { army } \\
\text { My friends } \\
\text { Television } \\
\text { Radio } \\
\text { Newspaper } \\
\text { Different } \\
\text { meeting } \\
\text { Other } \\
\text { sources }\end{array}$ & $\begin{array}{l}326 \\
111 \\
169 \\
84 \\
290 \\
20\end{array}$ & $\begin{array}{l}50.7 \\
17.3 \\
26.3 \\
13.1 \\
45.1 \\
\\
3.1\end{array}$ \\
\hline $\begin{array}{l}\text { Knowledge of } \\
\text { contraceptive methods }\end{array}$ & $\begin{array}{l}\text { Oral pills } \\
\text { IUCD } \\
\text { Injectables } \\
\text { Implant } \\
\text { Condom } \\
\text { Tubal ligation } \\
\text { Vasectomy }\end{array}$ & $\begin{array}{l}611 \\
382 \\
621 \\
564 \\
365 \\
229 \\
115\end{array}$ & $\begin{array}{l}95.0 \\
59.4 \\
96.6 \\
87.7 \\
56.8 \\
35.6 \\
17.9\end{array}$ \\
\hline $\begin{array}{l}\text { Visited by and counseled } \\
\text { on FP by health extension } \\
\text { worker at home in the last } \\
6 \text { months }\end{array}$ & $\begin{array}{l}\text { Yes } \\
\text { No }\end{array}$ & $\begin{array}{l}397 \\
246\end{array}$ & $\begin{array}{l}61.7 \\
38.3\end{array}$ \\
\hline $\begin{array}{l}\text { Visited health facility in the } \\
\text { last } 6 \text { months }\end{array}$ & $\begin{array}{l}\text { Yes } \\
\text { No }\end{array}$ & $\begin{array}{l}354 \\
289\end{array}$ & $\begin{array}{l}55.0 \\
45.0\end{array}$ \\
\hline $\begin{array}{l}\text { In the last } 6 \text { months HF } \\
\text { visit, health worker } \\
\text { counseled for FP }(n=354)\end{array}$ & $\begin{array}{l}\text { Yes } \\
\text { No }\end{array}$ & $\begin{array}{l}296 \\
58\end{array}$ & $\begin{array}{l}83.6 \\
16.4\end{array}$ \\
\hline $\begin{array}{l}\text { Do not know how to use } \\
\text { alternative choice FP }\end{array}$ & $\begin{array}{l}\text { Yes } \\
\text { No }\end{array}$ & $\begin{array}{l}75 \\
568\end{array}$ & $\begin{array}{l}11.7 \\
88.3\end{array}$ \\
\hline $\begin{array}{l}\text { Mothers attitude towards } \\
\text { modern contraceptive } \\
\text { methods }\end{array}$ & $\begin{array}{l}\text { Positive } \\
\text { attitude } \\
\text { Negative } \\
\text { attitude }\end{array}$ & $\begin{array}{l}458 \\
185\end{array}$ & $\begin{array}{l}71.2 \\
28.8\end{array}$ \\
\hline
\end{tabular}

when compared to their counterparts $(\mathrm{AOR}=2.2 ; 95 \%$ $\mathrm{CI}=1.3-3.8)$, and similarly study participants who had little perceived risk of pregnancy due to breast feeding were 2.3-times more likely to have experienced an unmet need for modern contraceptive use when compared to their counterparts $(\mathrm{AOR}=2.3 ; 95 \% \mathrm{CI}=1.3-4.1)$ (Table 5).
Table 4 Utilization of FP Among Currently Married Women, Damot Woyde District, SNNPR, Ethiopia, 2019 ( $N=643)$

\begin{tabular}{|l|l|l|l|}
\hline \multicolumn{2}{|l|}{ Characteristics } & Number & Percent \\
\hline $\begin{array}{l}\text { Current } \\
\text { utilization status } \\
\text { of family planning }\end{array}$ & Currently user & 292 & 45.4 \\
& Defaulter & 161 & 25.0 \\
& Never user & 190 & 29.5 \\
\hline $\begin{array}{l}\text { Reason of not } \\
\text { using modern } \\
\text { contraceptive } \\
(\mathrm{n}=35 \mathrm{I})\end{array}$ & Fear of side-effects & 131 & 37.3 \\
& Husband's opposition & 119 & 33.9 \\
& Little perceived risk of & 115 & 32.8 \\
& pregnancy due to & & \\
& infrequent sexual & & \\
& intercourse & & \\
& Little perceived risk of & 98 & 28.0 \\
& pregnancy due to BF & & \\
& Lack of knowledge & 67 & 19.1 \\
& Want to be pregnant & 46 & 13.1 \\
& Poor availability & 31 & 8.8 \\
& Poor access & 23 & 6.6 \\
& Family opposition & $1 \mathrm{I}$ & 3.1 \\
& Religion prohibition & 7 & 2.0 \\
& FP method failure & 4 & 1.1 \\
& Cannot get pregnant & 0 & 0 \\
& due to hysterectomy/ & & \\
& menopause & & \\
\hline
\end{tabular}

\section{Discussion}

The study revealed that there was a high $(26.3 \%)$ total unmet need for modern contraceptive methods $(18.8 \%$ for spacing and $7.5 \%$ for limiting). It also showed that educational status, total number of living children, little risk of pregnancy due to infrequent sex, and little risk of pregnancy due to breast feeding were independently associated factors of unmet need among currently married women in the study area.

This finding was in line with the study conducted in Enemay district $(25.6 \%)$ of North West Ethiopia, and Misha district (26.5\%) in SNNPR. ${ }^{11,12}$

However, the level was lower than the study done in Debre Berhan Town, Amhara, Ethiopia (30.9\%). ${ }^{13}$ This might be due to the high prevalence of early marriage in Amhara region. ${ }^{7}$ And much lower than in studies done in Kassala Eastern Sudan (44.8\%), rural areas of Burkinafaso (40.7\%), in Gulmi district in Nepal (48\%), as well as a study done in Eastern Democratic Republic of Congo $(56 \%) .{ }^{13-17}$ This might be due to variation in integration of family planning to other service area. This finding is higher than national and regional total unmet need $(22 \%$, $21 \%$, respectively), and higher than studies conducted in Dangila (17.4\%) Awi zone, Amhara region and Cameroon 
Table 5 Bivariate and Multivariate Logistic Regression Analysis of Factors Associated with Unmet Need of FP in Damot Woyde District, SNNPR, Ethiopia, 2019

\begin{tabular}{|c|c|c|c|c|c|c|}
\hline \multirow[t]{2}{*}{ Respondents Characteristics } & \multirow[t]{2}{*}{ Category } & \multicolumn{2}{|c|}{ Unmet Need } & \multirow[t]{2}{*}{$P$-value } & \multirow{2}{*}{$\begin{array}{l}\text { COR }(95 \% \\
\text { Cl) }\end{array}$} & \multirow{2}{*}{$\begin{array}{l}\text { AOR }(95 \% \\
\text { Cl) }\end{array}$} \\
\hline & & No & Yes & & & \\
\hline Age (years) & $\begin{array}{l}15-24 \\
25-34 \\
35-49\end{array}$ & $\begin{array}{l}126(78.3) \\
256(74.9) \\
92(65.7)\end{array}$ & $\begin{array}{l}35(21.7) \\
86(25.1) \\
48(34.3)\end{array}$ & $\begin{array}{l}0.405 \\
0.016^{*}\end{array}$ & $\begin{array}{l}\text { I } \\
\text { I.2(0.7,I.9) } \\
\text { I.8 (I.I-3.I) }\end{array}$ & $\begin{array}{l}\text { I } \\
\text { I.05(0.5,2.07) } \\
\text { I.24(0.4-,3.2) }\end{array}$ \\
\hline Education & $\begin{array}{l}\text { Unable to read } \\
\text { and write } \\
\text { Able to read } \\
\text { and write } \\
\text { Primary } \\
\text { Secondary } \\
\text { Certificate and } \\
\text { above }\end{array}$ & $\begin{array}{l}133(62.4) \\
31(75.6) \\
191(78.3) \\
72(79.1) \\
47(87)\end{array}$ & $\begin{array}{l}80(37.6) \\
10(24.4) \\
53(21.7) \\
19(20.9) \\
7(13)\end{array}$ & $\begin{array}{l}<0.001^{* * * *} \\
0.156 \\
0.152 \\
0.234\end{array}$ & $\begin{array}{l}4.0(1.7-9.4) \\
2.1(0.74-6.3) \\
1.8(0.8-4.3) \\
1.7(0.7-4.5) \\
1\end{array}$ & $\begin{array}{l}4.3(1.3-14.7) \\
\text { I.6 (0.4-7.0) } \\
\text { I. } 4(0.4-4.8) \\
\text { I.6 (0.5-5.6) } \\
\text { I }\end{array}$ \\
\hline Occupation & $\begin{array}{l}\text { Housewife/ } \\
\text { unemployed } \\
\text { Employed }\end{array}$ & $\begin{array}{l}314(71.9) \\
160(77.7)\end{array}$ & $\begin{array}{l}123(28.1) \\
46(22.3)\end{array}$ & 0.119 & $\begin{array}{l}\text { I.4 (0.9-2.0) } \\
\text { I }\end{array}$ & $\begin{array}{l}0.8(0.5-1.5) \\
\text { I }\end{array}$ \\
\hline Income (ETB) & $\begin{array}{l}\text { Below } 400 \\
401-745 \\
746-1,220 \\
\text { Above I,220 }\end{array}$ & $\begin{array}{l}173(66.3) \\
141(73.4) \\
80(81.6) \\
80(87)\end{array}$ & $\begin{array}{l}88(33.7) \\
51(26.6) \\
18(18.4) \\
12(13)\end{array}$ & $\begin{array}{l}0.000 * * * \\
0.012 * \\
0.317\end{array}$ & $\begin{array}{l}3.4(1.7-6.5) \\
2.4(1.2-4.8) \\
\text { I.5 (0.7-3.3) } \\
\text { I }\end{array}$ & $\begin{array}{l}2.2(0.8-5.7) \\
\text { I.3 }(0.5-3.2) \\
0.6(0.2-1.7) \\
I\end{array}$ \\
\hline Total number of alive children & $\begin{array}{l}\text { No child } \\
1-2 \\
3-4 \\
5 \text { and above }\end{array}$ & $\begin{array}{l}46(80.7) \\
154(79) \\
125(73.1) \\
149(67.7)\end{array}$ & $\begin{array}{l}\text { II }(19.3) \\
41(21) \\
46(26.9) \\
71(32.3)\end{array}$ & $\begin{array}{l}0.777 \\
0.253 \\
0.059\end{array}$ & $\begin{array}{l}\text { I } \\
\text { I.I (0.5-2.3) } \\
\text { I.5 (0.7-3.2) } \\
2.0(0.9-4.1)\end{array}$ & $\begin{array}{l}\text { I } \\
2.0(0.9-3.4) \\
2.8(1.1-7.8) \\
4.5(1.6-13.1)\end{array}$ \\
\hline Exposure to media (radio or TV) & $\begin{array}{l}\text { No } \\
\text { Yes }\end{array}$ & $\begin{array}{l}245(70) \\
229(78.2)\end{array}$ & $\begin{array}{l}105(30) \\
64(21.8)\end{array}$ & $0.02 *$ & $\mathrm{I} .5(\mathrm{I} . \mathrm{I}-2.2)$ & $\begin{array}{l}0.7(0.4-1.3) \\
\text { I }\end{array}$ \\
\hline Age at first marriage & $\begin{array}{l}\text { Below } 18 \\
18-24 \\
25-34\end{array}$ & $\begin{array}{l}143(68.1) \\
305(75.7) \\
26(86.6)\end{array}$ & $\begin{array}{l}67(31.9) \\
98(24.3) \\
4(13.4)\end{array}$ & $\begin{array}{l}0.046 * \\
0.180\end{array}$ & $\begin{array}{l}3.0(1.0-9.1) \\
2.1(0.7-6.1) \\
\text { I }\end{array}$ & $\begin{array}{l}\text { I.7 }(0.4-7.0) \\
0.9(0.2-3.7) \\
\text { I }\end{array}$ \\
\hline Do not know about alternative choice of FP & $\begin{array}{l}\text { No } \\
\text { Yes }\end{array}$ & $\begin{array}{l}432(76.1) \\
42(56)\end{array}$ & $\begin{array}{l}136(23.9) \\
33(44)\end{array}$ & $<0.001 * * *$ & I $2.5(1.5-4.1)$ & I.2(0.5-2.8) \\
\hline Discussion with sexual partner on F/P & $\begin{array}{l}\text { No } \\
\text { Yes }\end{array}$ & $\begin{array}{l}91(64.1) \\
383(76.4)\end{array}$ & $\begin{array}{l}51(35.9) \\
118(23.6)\end{array}$ & $0.003^{* *}$ & $\begin{array}{l}1.8(1.2-2.7) \\
\mathrm{I}\end{array}$ & $\begin{array}{l}\text { I.2 }(0.5-3.3) \\
\text { I }\end{array}$ \\
\hline Visiting health facilities in the last 6 months & $\begin{array}{l}\text { No } \\
\text { Yes }\end{array}$ & $\begin{array}{l}96(69.1) \\
378(75)\end{array}$ & $\begin{array}{l}43(30.9) \\
126(25)\end{array}$ & 0.160 & $\begin{array}{l}1.3(0.9-2.0) \\
\text { I }\end{array}$ & $\begin{array}{l}0.6(0.4-1.2) \\
I\end{array}$ \\
\hline $\begin{array}{l}\text { Little perceived risk of pregnancy due to } \\
\text { infrequent sexual intercourse }\end{array}$ & $\begin{array}{l}\text { No } \\
\text { Yes }\end{array}$ & $\begin{array}{l}135(57.2) \\
47(40.9)\end{array}$ & $\begin{array}{l}101(42.8) \\
68(59.1)\end{array}$ & $0.004 * *$ & $1.9(1.2-3.0)$ & $\begin{array}{l}\text { I } \\
2.2(1.3-3.8)\end{array}$ \\
\hline $\begin{array}{l}\text { Little perceived risk of pregnancy due to breast } \\
\text { feeding }\end{array}$ & $\begin{array}{l}\text { No } \\
\text { Yes }\end{array}$ & $\begin{array}{l}146(57.7) \\
36(36.7)\end{array}$ & $\begin{array}{l}107(42.3) \\
62(63.3)\end{array}$ & $<0.001 * * *$ & $\begin{array}{l}\text { I } \\
2.3(1.4-3.8)\end{array}$ & $\begin{array}{l}\text { I } \\
2.3(1.3-4.1)\end{array}$ \\
\hline Knowledge on family planning & $\begin{array}{l}\text { Poor } \\
\text { Good }\end{array}$ & $\begin{array}{l}100(64.9) \\
374(76.5)\end{array}$ & $\begin{array}{l}32(35.1) \\
115(23.5)\end{array}$ & $0.005^{* *}$ & $\begin{array}{l}\text { I.7 (I.2-2.6) } \\
\text { I }\end{array}$ & $\begin{array}{l}\text { I.2 }(0.6-2.0) \\
\text { I }\end{array}$ \\
\hline Attitude towards family planning utilization & $\begin{array}{l}\text { Negative } \\
\text { Positive }\end{array}$ & $\begin{array}{l}123(66.5) \\
351(76.6)\end{array}$ & $\begin{array}{l}62(33.5) \\
107(23.4)\end{array}$ & $0.008^{* *}$ & $\begin{array}{l}1.6(1.1-2.4) \\
\text { I }\end{array}$ & $\begin{array}{l}0.6(0.2-1.7) \\
\text { I }\end{array}$ \\
\hline
\end{tabular}

Notes: $* P<0.05, * * P<0.01, * * * P<0.001$. 
$(20.4 \%) .^{7,18,19}$ This might be due to the socio demographic variability, availability of logistics, and variation in implementation of compassion and respectful care provision regarding family planning methods.

The likelihood of an unmet need for contraception for women who were unable to read or write was higher when compared to those women who are educated to secondary level and above. This is in line with studies done in Misha District, SNNPR and Enemay District, Northwest Ethiopia, ${ }^{11,12}$ and Eastern Sudan. ${ }^{14}$ A possible reason is that women who are educated are more likely to gain knowledge about contraceptives by reading different reading materials and have increased access to contraceptive information from different media. This finding implies the need of expanding basic education at the community level in order to decrease the level of unmet need through empowering women through education.

This study also indicated that the total number of living children are one of the predictors for unmet need of modern contraceptive methods. Thus, women with one or more children have the demand for contraceptives, however due to different reasons they would be exposed to unmet need of family planning. In this study, among the study participants who had demanded contraceptives, only $45.4 \%$ reported their met demand. This is supported by studies carried out elsewhere. ${ }^{11,16,20,21}$ This might be due to the fact that women with adequate children need to control their fertility, leading to a high demand for contraceptives.

Little perceived risk of pregnancy due to infrequent sexual intercourse was another factor that mislead the women to the unmet need of family planning. This was the same with the studies conducted in rural areas of Burkina Faso. ${ }^{15}$ This might be due to a lack of fertility awareness. This finding implies that the chance of having of unwanted pregnancy for those women might be high. Therefore, the government should strengthen it's health education programs on how pregnancy can occur, safe sex, and the need of contraceptive method utilization to prevent it.

Perception of women with little perceived risk of pregnancy due to breast feeding that increases the probability to be an unmet need of family planning. This was similar with studies done in Northern Ethiopia and rural areas of Burkina Faso. ${ }^{18,22}$ This might be due to a lack of awareness on the right time for lactation amenorrhea. This finding implies that the need of health workers support to community on the timing of exclusive feeding and its frequency to reduce unwanted pregnancy.

\section{Limitation of the Study}

First, the information used in this study was based on selfreport. There may be some bias in the reporting, particularly around some of the sensitive issues that were incorporated. Therefore, to address these issues confidentiality was strictly maintained for study participants and the data collectors were oriented on collection of data. Moreover, the unmet need for modern contraceptive utilization was negative measurement in family planning measurements; it's better to study demand satisfied for modern contraceptive methods rather than unmet need. Demand satisfied for modern contraceptive method is one of SDG sub-goals under SDG3.

\section{Conclusion}

The prevalence of unmet need for modern contraceptive methods among currently married women is high and women have more unmet needs for spacing compared to unmet needs for limiting. The concerned bodies should expand basic education at the community level; strengthen health education programs which focused on fertility awareness, and the right time for lactation amenorrhea.

\section{Abbreviations}

EDHS, Ethiopian Demographic and Health Survey; F/P, family planning; MMR, maternal mortality rate; SDG, sustainable development goals.

\section{Data Sharing Statement}

All data will be available on reasonable request.

\section{Consent for Publication}

It is not applicable.

\section{Ethics Approval and Consent to Participate}

Ethical clearance was obtained from the Institutional Ethical Review Board (IERB) of Wolaita Sodo University, College of Health Sciences. An official letter of permission was written to Wolaita Sodo Health Bureau to the respective Damot Woyde district. Informed oral consent was obtained from study participants after explaining the objective of the study, and the benefit and risks of participating in this study. 


\section{Acknowledgments}

We are very grateful to Wolayta Sodo University for provision of ethical clearance for the conduct of this study, Wolayta Zonal health department for the logistic support to this study, and all study participants for their commitment in responding to our questionnaire.

\section{Author Contributions}

All authors made a significant contribution to the work reported, whether that is in the conception, study design, execution, acquisition of data, analysis and interpretation, or in all these areas; took part in drafting, revising, or critically reviewing the article; gave final approval of the version to be published; have agreed on the journal to which the article has been submitted; and agree to be accountable for all aspects of the work.

\section{Funding}

No funding was obtained.

\section{Disclosure}

The authors declare that they have no competing interests.

\section{References}

1. David Hubacher D, Trussell J. A definition of modern contraceptive methods. ELSEIVER Contraception. 2015;92(5):420-421. doi:10.1016/j.contraception.2015.08.008

2. Health, F.D.R.o.E.M.o. NationalL Guidline for Family Planning Service in Ethiopia. 2011

3. Knerr W. The Unmet Need for Family Planning. International Planned Parenthood Federation; 2012.

4. UN-DESA. "Sustainable Development Goal 3: Ensure Healthy Lives And Promote Well-Being For All At All Ages,",2017,]. Sustainable Development Knowledge Platform; May 17, 2017.

5. FMOH, F.D.R.o.E., MOH. National Reproductive Strategies of Ethiopia, 2016-2020. 2015.

6. United Nations, D.o.E.a.S.A., Population Division. World Family Planning. United Nations; 2017.

7. Central Statistical Agency. 2016 Ethiopia Demographic and Health Survey. 2016:1-59.

8. agency, C.s. Ethiopian Demographic Health Survey. 2019.
9. Bradley SEK. Revising Unmet Need for Family Planning. Maryland, USA: ICF International Calverton; 2012. DHS Analytical Studies No. 25.

10. agency, C.s. Ethiopian Demographic and Health Survey 2011. 2011:1-412.

11. Chafo K, Doyore F. Unmet need for family planning and associated factors among currently married women in Misha District, Southern Ethiopia: a Cross Sectional Study. J Womens Health Care. 2014;3 (165):2167-0420.1000165. doi:10.4172/2167-0420.1000165

12. Getiye Dejenu MAAAA. Prevalence and associated factors of unmet need for family planning among married women in Enemay District, Northwest Ethiopia: a Comparative Cross-Sectional Study. Glob J Med Res. 2013;13(4).

13. Worku SA, Ahmed SM, Mulushewa TF. Unmet need for family planning and its associated factor among women of reproductive age in Debre Berhan Town, Amhara, Ethiopia. BMC Res Note. 2019;12:143. doi:10.1186/s13104-019-4180-9

14. Ali AAA, Okud A. Factors affecting unmet need for family planning in Eastern Sudan. BMC Public Health. 2013;13(1):102. doi:10.1186/ 1471-2458-13-102

15. Wulifan JKM, Jahn J, Hien A. Hervé, factors associated with contraceptive use among women of reproductive age in Rural Districts of Burkina Faso. J Health Care Poor Underserved. 2017;28 (1):228-247. doi:10.1353/hpu.2017.0019

16. Kandel NR. Unmet need for contraception and its associated factors among married women of reproductive age in Simichaur VDC of Gulmi District. Health Prospect. 2012;11:11-14. doi:10.3126/hprospect.v11i0.7423

17. Mathe JK, Kasonia KK, Maliro AK. Barriers to adoption of family planning among women in Eastern Democratic Republic of Congo. Afr J Reprod Health. 2011;15(1).

18. Genet E, Abeje G, Ejigu T. Determinants of unmet need for family planning among currently married women in Dangila town administration, Awi Zone, Amhara regional state; a cross sectional study. Reprod Health. 2015;12(1):42. doi:10.1186/s12978-015-0038-3

19. Ajong ABN, Njotang PN, Yakum MN. Determinants of unmet need for family planning among women in Urban Cameroon: a cross sectional survey in the Biyem-Assi Health District, Yaoundé. BMC Womens Health. 2016;16(1):4. doi:10.1186/s12905-016-0283-9

20. Mekonnen W, Worku A. Determinants of low family planning use and high unmet need in Butajira District, South Central Ethiopia. Reprod Health. 2011;8(1):37.

21. Waqas Hameed SKA, Bilgrami M, Ishaqe M. Determining the factors associated with unmet need for family planning: a cross-sectional survey in 49 districts of Pakistan. PJPH. 2011;1:1.

22. Adebowale SA, Palamuleni ME. Determinants of unmet need for modern contraception and reasons for non-use among married women in rural areas of Burkina Faso. Afr Pop Stud. 2014;28 (1):499. doi:10.11564/28-1-503
Open Access Journal of Contraception

\section{Publish your work in this journal}

Open Access Journal of Contraception is an international, peerreviewed, open access, online journal, publishing original research, reports, reviews and commentaries on all areas of contraception. In addition to clinical research, demographics and health-related aspects, the journal welcomes new findings in animal and preclinical

\section{Dovepress}

studies relating to understanding the biological mechanisms and practical development of new contraceptive agents. The manuscript management system is completely online and includes a very quick and fair peer-review system. Visit http://www.dovepress.com/testimonials. php to read real quotes from published authors. 